\title{
A Gender Mainstreaming Approach of Social and Economic Impact Management during the Covid- 19 Pandemic in Urban Settlements
}

\author{
Landung Esariti ${ }^{*}$, Euginia Calista Yonita ${ }^{1}$, and Artiningsih ${ }^{1}$ \\ ${ }^{1}$ Department of Urban and Regional Planning, Faculty of Engineering, Diponegoro University, \\ Semarang, Indonesia
}

\begin{abstract}
This article describes the gender mainstreaming based community approach in Polaman Village, Mijen District in reducing the risk of non-natural disasters for the Covid-19 pandemic. This study used the quantitative approach and data collection technique by interviewing 3 community representatives and distributing questionnaires to 24 households. Assessment of gender mainstreaming indicators used the scoring analysis with 5 indicators, i.e., access, benefits, participation, control and inclusion. The results showed that Kampung Siaga Candi Hebat was formed through the establishment of a food storehouse to help meet the needs of food security during the pandemic, freshwater cultivation through involving people affected by layoffs, and the construction of a health center as a monitoring facility, and an isolation accommodation for residents affected by the Covid-19 virus. However, in the management of residential spaces, impediments were still found in terms of lack of availability and management of existing green public spaces and the lack of management integration of waterways, water disposal and garbage. In conclusion, the control aspect was found to be the most influential, with a contribution value of $21 \%$ out of $75 \%$. Accordingly, accustomization of the gender mainstreaming approach showed a value of $75 \%$ which can be considered quite effective.
\end{abstract}

\section{Introduction}

The Kampung Siaga Covid-19 or Kampung Siaga Candi Hebat (KSCH) program was established to stop the spread of the Coronavirus and increase the economic resilience of families in the city of Semarang. The program is manifested through services and enforcement of policies such as comprehensive and stringent health protocols, temperature check-ups for newcomers and outbound travelers, provision of quarantine spaces, distribution of basic foods, assistance and food security among neighbors, storehouses for residents, and provision of vitamins and nutritious food for residents [1]. The government's initial step in preventing Covid-19 through this Kampung Siaga program has succeeded in reducing the number of positive cases from 970 to 622 people [2]. Community empowerment

* Corresponding author: landungesariti@lecturer.undip.ac.id 
is also carried out to reduce the impact of decreasing community income, as in the case of Polaman Village, Mijen District. This empowerment provides the community with social capital development and encourages capacity building [3]. The activities carried out are in the form of agriculture, freshwater fisheries, and developments of micro, small and medium enterprises. Outputs from the established businesses within the program will be used for food sources or sold with promotional assistance from the Semarang City Government [4].

According to Lassa, et.al [5], there are approaches available for a community to be able to reduce disaster risks, for instance, interpretation, priority management/reduction, monitoring, and evaluation of disaster reduction efforts known as Community Based Disaster Risk Management (CBDRM). These activities are implemented so that people in residential areas, especially in Polaman Village, Mijen District could adapt in dealing with Covid-19 through the Kampung Siaga Bencana (Village Disaster Management) program for nonnatural disasters. Especially during the pandemic, every gender is vulnerable in facing the spread of the Covid-19 Virus in terms of their economic, social, and health conditions. Women, children, the elderly, disabled people, and the poor are the most vulnerable groups in face of this pandemic as access to resources specially designated and devoted to them is still quite minimal. The gender mainstreaming approach plays a role in achieving gender equality and justice in integrating the experiences, needs, and aspirations of women and men into policies and programs designed to operate CBDRM starting from planning, budgeting, implementing, and monitoring [6].

The gender mainstreaming concept was used to study community-based disaster risk management, Kampung Siaga Candi Hebat, in Polaman Village, Mijen District. This research looks at whether gender mainstreaming has been implemented in the Kampung Siaga Candi Hebat program in empowering the area to become independent. Through this insufficiencies may be identified during the program implementation so that improvements can be made to provide awareness within local community activities to create gender justice and equality [7]. A program that reflects the preparedness of a village in dealing with disasters is the quintessence of Community Based Disaster Risk Management. The program will be reviewed to ensure that its implementation is not only carried out on a community basis, but also its comprehensive implementation in gender mainstreaming aspects such as access, participation, control, benefits, and inclusion so that the sustainability of the program implementation could be maximized.

\section{Methodology}

The present research looks at the Kampung Siaga Candi Hebat program implemented within the scope of RT.001/RW.002 Polaman Village which accommodates 500 people. The area consists of 74 hectares with designated centers to hold activities with details of the locations as follows:

a. Agricultural land as for food storage/public kitchen: $136 \mathrm{~m}^{2}$

b. Freshwater Fishery Area: 1,409 m²/0.14 Ha

c. Center for Kampung Siaga Candi Hebat and PPKM (Enforcement of Restrictions on Public Activities): $46.3 \mathrm{~m}^{2}$

d. Isolation Facility: $31.3 \mathrm{~m}^{2}$

This study used a non-probability sampling technique which would allow each respondent to be specially selected as a sample through stratified sampling. Through stratified sampling, respondents focused on the main actors in all activities of the Kampung Siaga Candi Hebat program by dividing the population into separate groups to reduce the amount of homogeneity in the respondent's results [8]. Sampling was taken with a maximum confidence level of $85 \%$ with an error of $15 \%$. The sample consisted of 24 respondents with 6 defined strata compositions, namely, Polaman Village Officials (Village, RW, RT, and 
community organization actors), farmer group actors, MSME actors, food security actors, Kampung Siaga Candi center actors, and fishery actors. Stratified are chosen within these actors as the control community who were aware with the information of the advantage and weaknesses of the program [9].

The analysis technique involved descriptive and statistical analysis. Descriptive analysis was used to identify the profile of the village and compare the implementation of the program in the Polaman Village. A questionnaire is used for collecting data and the question adapted from International Organization for Migration and Community Disaster Risk Management standard for Indonesia to access the indicators of disaster risk management which includes carrying out gender mainstreaming to make sure the representation question involving gender-balanced and responsive to the disaster condition [10]. Statistical analysis was used to process results from the questionnaire with the lowest answer scale of 1 and the highest of 5. The use of this range aims to measure the Likert scale which is effective for measuring the subjective opinion of the respondent regarding their behavior coping Covid-19 Pandemic [11]. The data processing was done by multiplying the respondents' total chosen answers by their credit which was then totaled into the value of each assessment indicator. Assessment indicators are supporting components with regards to gender, namely, access, participation, control, benefits, and inclusion.

Table 1. Gender Mainstreaming Assessment Ratio.

\begin{tabular}{|c|c|c|}
\hline Scale & Description & Percentage \\
\hline Excellent & Kampung Siaga Candi Hebat highly implements Gender \\
Mainstreaming & $81-100 \%$ \\
\hline Above Average & Kampung Siaga Candi Hebat applies Gender Mainstreaming & $61-80 \%$ \\
\hline Average & $\begin{array}{c}\text { Kampung Siaga Candi Hebat implements Gender Mainstreaming } \\
\text { but not all activities are able to involve and provide benefits to } \\
\text { all genders }\end{array}$ & $41-60 \%$ \\
\hline Below Average & $\begin{array}{c}\text { Kampung Siaga Candi Hebat is less able to implement Gender } \\
\text { Mainstreaming }\end{array}$ & $21-40 \%$ \\
\hline Very Poor & Kampung Siaga Candi Hebat has not implemented Gender \\
Mainstreaming & $0-20 \%$ \\
\hline
\end{tabular}

\section{Results and Discussion}

\subsection{Economic and Social Impact Management Analysis}

The activities entailed in the Kampung Siaga Candi Hebat program as a form of adaptation to the Corona Pandemic conditions are as follows:

a. Food Security Program

This program is aimed at supporting the food security of each community members in Polaman Village. The community member would receive ready-to-eat meals consisting of nutritious foods, fruits, and vegetables. The types of foods that are distributed are packaged rice, milk, fruit, side dishes, and herbal drinks. This activity is carried out periodically about three to five times a week. The foods are sourced from community food crops and CSR assistance (Superindo).

b. Covid-19 Alert Post Development Program 
The Covid-19 Alert Post is a health post in Polaman Village. The activities carried out in the post are temperature check-ups for newcomers and data collection of inbound visitors who will enter the Polaman Village area. The post is also a center for monitoring the spread of Covid-19 equipped with medical devices and personal protective equipment. The post houses 1 health officer from the Mijen Subdistrict Health Center and service is carried out in the morning for the whole week.

c. Women Farmers Group Formation Program

The program, which is based on community activities in agriculture, is targeted at gardening activities in houses. This activity aims to contribute to food security. Every resident and the community cultivates plants that can later be used as food for personal consumption or used for food security programs. This program also promotes alternative urban land use or urban farming. Apart from house yards, the $136 \mathrm{~m} 2$ land belonging to one of the residents has become agricultural land managed by the Polaman Village Women Farmers Group.

d. Community Food Storage Program

Community food storage is a sustainability program aimed to help with the local economy as well as a form of expansion of the food security activities. The food storage house is a collective community effort in collecting food and groceries and storing them in one place and to be managed and distributed to people in need. In addition, processed food, such as chips, is also managed for MSMEs to continue to assist in the sustainability of food aid for the people in Polaman Village through profit from the sale of available products.

e. Economic Activity Program through Fisheries and Farming

This program is provided to help people who have been laid off during the Covid-19 pandemic. Through aquaculture and farming, people are required to be able to cultivate freshwater fish that can be traded or consumed for the community. This innovation was formed through the initiative of one of the Polaman residents which gave rise to a small association that trains residents to have fishery skills to help them financially and increase the skills of the people being trained.

In terms of economy, a pandemic is a difficult period where every individual to limit social activities which reduce various options for people to seek income. Especially for lowincome people, they are vulnerable to bigger economic impact with decrease in income sources and therefore worsening economic conditions during the pandemic [12] as proven by the respondents' answers. The World Bank currently predicts that global poverty during the pandemic will push 40-60 million people towards extreme poverty, and 195 million people will experience job losses [13].

To support the creation of suitable social interactions in the face of a crisis, special networks need to be formed to connect relations which can be manifested through the formation of organizational groups and committee teams. Such networks create convenience between individuals and groups with access to various resources, information, physical and financial assistance, as well as emotional support through kinship [14]. In addition, supporting factors, such as the working background, have a big influence on the ability of the citizens to be able to understand and then pioneer in handling the conditions that occur in their neighborhoods [15].

Initiatives carried out by the community are an adaptive response to bring together people who grow organically, especially in rural environments. Emergency thinking is needed to carry out bottom-up planning to deal with the pandemic with the support of the village government and the community that mutually supports its members, especially during the pandemic so that basic needs services, social protection, socialization, health, and other pandemic handling responses can be made with the participation of the community in adapting during a pandemic [16]. 


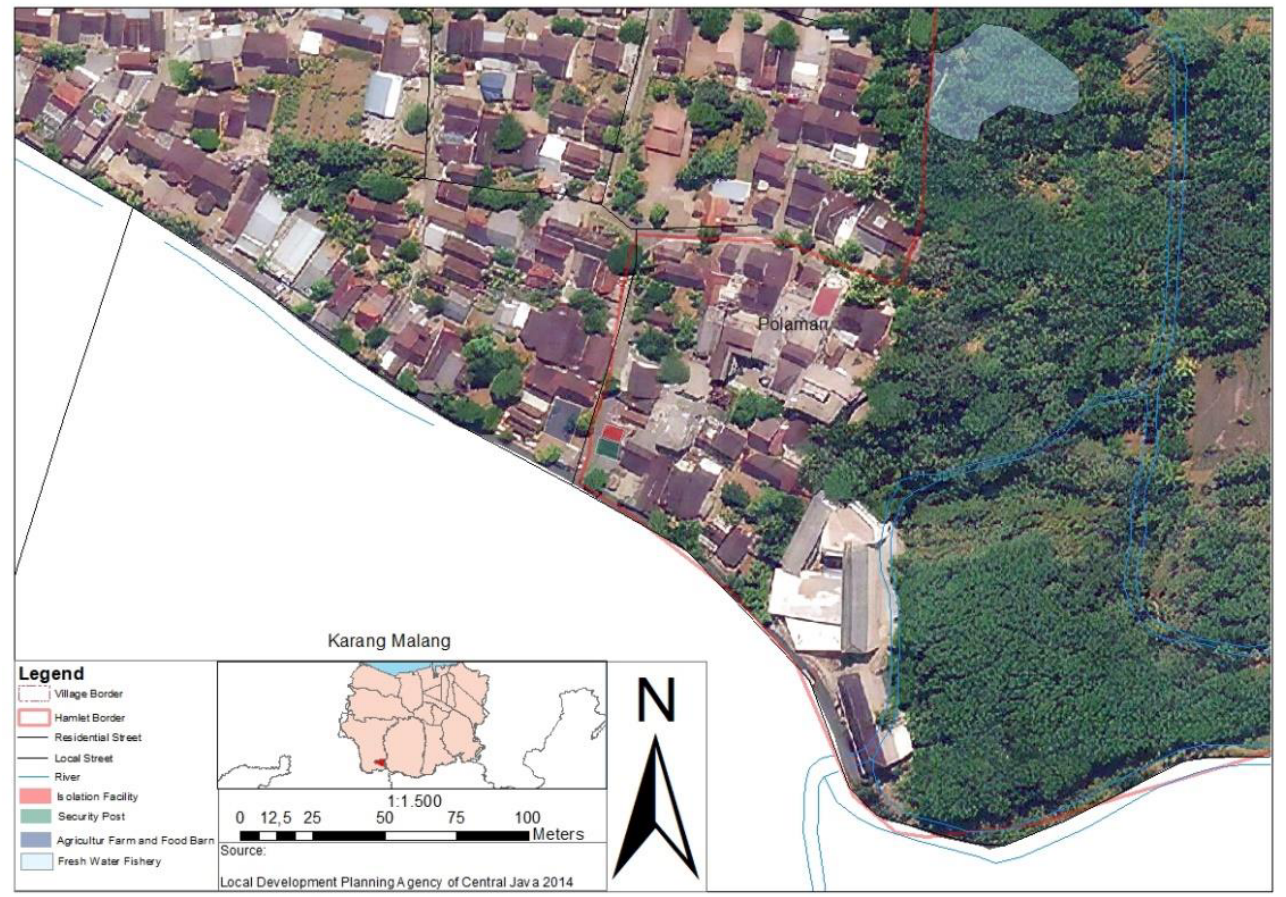

Fig. 1. Map of the Kampung Siaga Candi Hebat Program Area in Polaman Village.

To support the creation of an area free of the Covid-19 virus, the first response of the community was to a post or center for response and then ensure food availability. This is evidenced by the use of 2 private areas for food storage and freshwater fisheries. The creation of Kampung Siaga Candi Hebat spaces was advantageous in keeping the main interest of initiators to maintain the food supply of the community following the condition of the natural resources owned by the Polaman Village. Agriculture and plantation are the main players in promoting Kampung Siaga Candi Hebat, in which community activities in farming are mobilized towards the management of food storage and public kitchens to be able to support the community during a period of activity restrictions and the onset of a pandemic to meet the nutritional needs of the community.

Public spaces created in Kampung Siaga Candi Hebat can be accessed easily, especially for the people of RW.002, Polaman Village, with a travel time of fewer than 5 minutes from their residences. Outside of RW.002 needs for health apparatus were not able to be fulfilled optimally as the establishment of the Kampung Siaga Candi Hebat was focused in RT.001/RW.002, Polaman Village. Within the Kampung Siaga Candi Hebat area, spaces were settled and were able to meet requirements needed for isolation, food storage, and logistics storage which is all located in the main post which is close to the local road as a connecting road for service centers, especially in Semarang City. The distance from the post/isolation facility to the nearest public health center namely PUSKESMAS MIJEN, is $7.5 \mathrm{~km}$ with a travel time of \pm 15 minutes.

The technology literacy and physical building condition requirements were not able to be fully adopted by the community as the community is still rural and is located in the outermost area of Semarang City. Barriers in establishing buildings or facilities in a pandemic can be caused by funding constraints and resistance from residents who have been accustomed to organic village settlements. Thus, the adaptation carried out by the community informing 
space was the allocation of land for food security and safeguard on the main road for isolation, logistics warehouses, and monitoring of community conditions.

According to Megahed \& Ghoneim [17], the anti-virus-built environment can be adapted along with the digitalization era. In any case, for rural and urban areas, the ability of villages to support their environment can facilitate the operationalization of independent isolation. However, this must be supported by the willingness of the community to depend on the potential of their respective villages. The government needs to support activities of production in villages that can assist in provisions for people in non-productive areas needing such assistance which are also vulnerable to stagnation of any productivity of a village [18].

The fallibility experienced in the establishment of the KSCH in Polaman Village is the lack of attention to green public spaces and utilities (drains, water disposal, and garbage). The existence of green public spaces ensures clean water, and good waste management will support good environmental health conditions (Ahsan, 2020). The increasing consumption of water during the pandemic led to a decrease in the availability of sufficient clean water for the residential areas. Additionally, most members of the Polaman Village use wells as a source of water. The green public space in question is a space capable of providing physical interaction with nature and space that can provide food production to reduce excess risk during a pandemic (Megahed \& Ghoneim, 2020). The natural environment of Polaman Village is dominated by agriculture wherein the use of public green space for food production has been carried out as a form of interaction with nature. In contrast, the production of household waste has seen an increase with more demands on food delivery services of readymade meals and inherently single-use plastics. In addition to reducing the aesthetics of the environment, such waste products can cause the spread of other diseases in the neighborhood.

\subsection{Analysis of Gender Mainstreaming in Kampung Siaga Candi Hebat}

Based on the comparative analysis carried out, evacuation and health-related activities, especially in terms of logistics and public kitchens, have involved trained individuals to deal with the pandemic and train the community to be responsive and alert. Moreover, supply of food during isolation, provision of health personnel, health posts, and isolation rooms, as well as logistic management in distribution activities for residents are also available. The drawbacks in the efforts made are that health workers and trained personnel that are available are not members of the Polaman Village community. The community has received warnings about the Covid-19 pandemic but its handling has not been properly carried out, such as in providing handwashing stations in housing environments, enforcing the use of masks, and keeping the environment clean.

The next stage of the act was the early warning against disasters. Emergency response actions were carried out in the form of security guards in Polaman Village and monitoring of positive cases from increasing as per the last reported case in November. Monitoring for the Covid-19 case has been carried out, but case tracing has not been carried out optimally by the Covid-19 handling team. The monitoring activities only revolve around reporting cases experienced by community members but are limited to the clusters or locations where victims are exposed to the virus. As for socialization and capacity building of the community, training and openings of job opportunities were provided. However, the training and employment offers have not helped the economy of the entire community as the training implemented rely on programs from the Community Service Program (KKN) from university students and the jobs available from the freshwater fisheries are mostly offered for the communities around RT .001 because the cultivating land and business capital are still very minimal.

Protection measures involve activities in managing incoming visitors and operations in resident control. The emergency response component in this activity is to deploy security personnel from RW and RT members in the mornings assisted by BABINSA and 
BABINKAMTIBMAS officials. However, in carrying out this activity, the availability of space for isolation of visitors and residents when exposed to Covid-19 is still minimal, there is only 1 isolation room with a mattress capacity for 2 people. Data and information-related activities that have been carried out include the formation of a committee team and the promotion of village activities in the mass media. However, data collection on activities for prevention, monitoring, and tracing of the Covid-19 case is still not properly integrated and thus cannot provide proof of the routine integrity of such efforts apart from direct observation in the field.

concept of the non-natural disaster village preparedness, Kampung Siaga Bencana, program is adjusted to the conditions of the activities recommended by the Ministry of Social Affairs in the Regulation of the Minister of Social Affairs of the Republic of Indonesia Number 128 of 2011 Article 3 on Kampung Siaga Bencana (Village Disaster Preparedness) in empowering the community, that is to form community organizations and disaster preparedness networks to strengthen the social relations of each member of the community. However, solid waste and clean water utility for housing in Kampung Siaga Candi Hebat have not received prominent attention due to the more dominant focus of the program to provide the community needs to be able to survive during the pandemic through accomplishing food supply and good nutritional intake of the residents, promoted by Polaman Village, as well as the creations of job opportunities for people who have experienced job losses. Solid waste and clean water managements hold significant importance during the pandemic as the amount of household waste and the need for clean water increases as a result of increased household activities compared to normal conditions. Based on other research, the need for clean household water in Indonesia has increased by 400 liters per day to 900 liters per day [19], while household waste expenditure, according to the Ministry of Environment and Forestry, has increased 36\% during the pandemic [20].

Table 2. Gender Mainstreaming Assessment.

\begin{tabular}{|c|c|c|c|c|}
\hline Indicator & Criteria & Score & Credit & Value \\
\hline \multirow[t]{2}{*}{ Access } & $\begin{array}{l}\text { Available access to physical and non-physical } \\
\text { assistance during the Covid-19 pandemic }\end{array}$ & 94 & $10 \%$ & 9.4 \\
\hline & $\begin{array}{l}\text { Available knowledge and opportunity to take part in } \\
\text { the Kampung Siaga Candi Hebat program }\end{array}$ & 96 & $10 \%$ & 9.6 \\
\hline Participation & $\begin{array}{l}\text { Community contribution in the Kampung Siaga } \\
\text { Candi Hebat Activities }\end{array}$ & 94 & $20 \%$ & 18.8 \\
\hline \multirow[t]{2}{*}{ Control } & $\begin{array}{l}\text { The use of land to support the Kampung Siaga } \\
\text { Candi Hebat activities }\end{array}$ & 107 & $10 \%$ & 10.7 \\
\hline & Community contribution in the use of resources & 104 & $10 \%$ & 10.4 \\
\hline \multirow[t]{2}{*}{ Benefit } & $\begin{array}{l}\text { Existence of tangible benefits from the pandemic } \\
\text { response in the residential environment }\end{array}$ & 98 & $10 \%$ & 9.8 \\
\hline & $\begin{array}{l}\text { An increase in the standard of living of people who } \\
\text { can support the economy during the Covid-19 } \\
\text { pandemic }\end{array}$ & 99 & $10 \%$ & 9.9 \\
\hline Inclusion & $\begin{array}{l}\text { Increased gender participation in every activity of } \\
\text { the Kampung Siaga Candi Hebat program }\end{array}$ & 102 & $20 \%$ & 20.4 \\
\hline \multicolumn{3}{|l|}{ Total } & $100 \%$ & 99 \\
\hline \multicolumn{4}{|c|}{ Maximum Score } & 132 \\
\hline \multicolumn{4}{|c|}{ Minumum Score } & 24 \\
\hline \multirow{2}{*}{\multicolumn{4}{|c|}{ Result }} & $99 / 132$ \\
\hline & & & & $75 \%$ \\
\hline
\end{tabular}

In the assessment of access, participation, control, benefit, and inclusion aspects, an accumulative result of gender mainstreaming was obtained at a high level of $75 \%$. This value reflects that the current Kampung Siaga Candi Hebat program has implemented gender 
mainstreaming relatively effectively. This value, if categorized in the predetermined value range, places the Kampung Siaga Candi Hebat program in Polaman Village in an excellent category wherein gender mainstreaming has been implemented. The results obtained are quite satisfying with classification into the second place. However, based on the observation results, the answers obtained can be considered biased, where most of the respondents play active roles in the Kampung Siaga Candi Hebat program. The answers given can also be considered as misleading in providing the impression of satisfaction as an outcome to avoid unfavorable predictions and to invite good judgments [21].

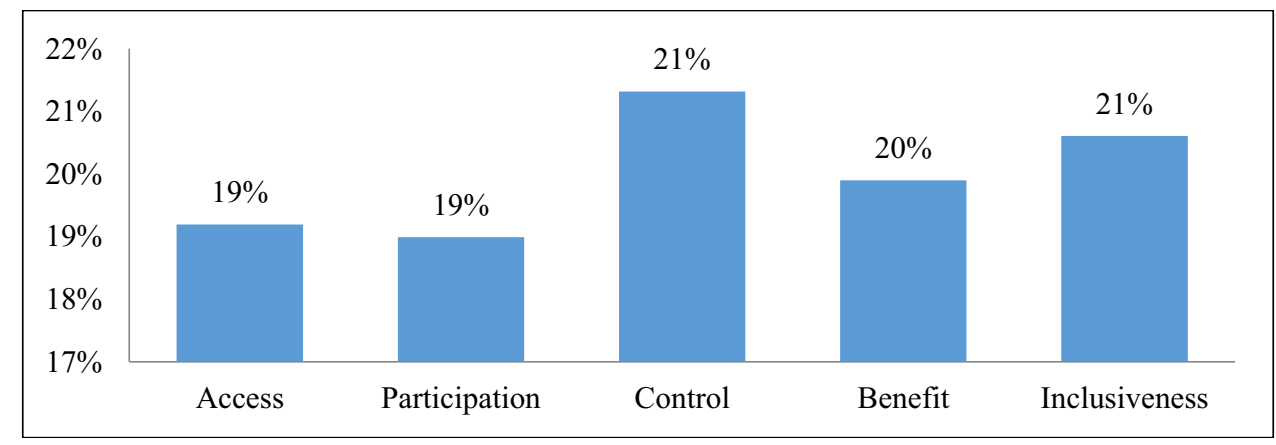

Fig. 2. Comparison of Gender Mainstreaming Aspects.

The control aspect is the most influential aspect, namely the existence of community control over the resources managed during the Covid-19 pandemic with a contribution value of $21 \%$ (score 21.1 ) out of $75 \%$ of the total value of gender mainstreaming that plays a role in the Kampung Candi Siaga Hebat program. The resource control in question includes the harvest of food from the agricultural land worked on by the community, that is attempted, the opportunity to be treated in an isolation room, and the receival of donation or assistance quota allocated to each resident. Participations of the productive and non-productive age groups, women and men of various economic conditions, and business actors in the Kampung Siaga Candi Hebat program are put into efforts, but within the implementation, only the main actors are heavily involved and not all actors are involved in program planning. The lack of skilled community personnel, along with broad community involvement, has caused the value of gender mainstreaming in the Siaga Candi Hebat Village of Polaman Village to not be maximized. However, as for the distribution of assistance obtained, each community member has received adequate rights and portions to harvest crops and receive basic food assistance provided by CSR and the Government.

\section{Conclusion}

This research describes that the implementation of gender mainstreaming has proven to be quite effective in the Kampung Siaga Candi Hebat program in Polaman Village. Two recommendations are proposed based on several considerations of implications related to environmental planning. First, the new adaptations in the environmental planning program need to pay attention to gender mainstreaming components, not only for the benefit of the community but to address environmental problems that are unique and diverse in each study location. Gender mainstreaming will answer the needs of each individual in facing risks in the development of an environment and help identify problems that will be faced differently by each gender. Second, environmental development programs need to involve the community at large and not only the assigned main figures so that the composition of the members is evenly distributed. However, the willingness of the community needs to also be 
present through the smallest form of participation so that the whole community understands the program being implemented.

\section{References}

1. Semarang City Contributor. Kampung Siaga Candi Hebat, Gerakkan Aktivitas Ekonomi Masyarakat. (2020)

2. Setiawan, H. Kampung Siaga Covid-19 Tingkatkan Kesadaran Warga Semarang. (2020)

3. Edwards, D. B. Shifting The Perspective on Community-based Management of Education: From Systems Theory to Social Capital and Community Empowerment. Int. J. Educ. Dev. 64, 17-26 (2019)

4. Widodo, A. Kampung Siaga Covid-19 di Kota Semarang, Bantu Warga yang Terdampak Pandemi. (2020)

5. Lassa, J. et al. Panduan Pengelolaan Risiko Bencana Berbasis Komunitas (PRBBK). 2 (2014)

6. State Minister for Women's Empowerment and Child Protection Republic of Indonesia. Peraturan Menteri Negara Pemberdayaan Perempuan dan Perlindungan Anak Republik Indonesia Nomor 11 Tahun 2011 Tentang Kebijakan Pengembangan Kabupaten/Kota Layak Anak. Phys. Rev. E (2011)

7. Khalifa, R. \& Scarparo, S. Gender Responsive Budgeting: A tool for Gender Equality. Crit. Perspect. Account. 102183, doi:10.1016/j.cpa.2020.102183. (2020)

8. Iarossi, G. The power of survey design: A user's guide for managing surveys, interpreting results, and influencing respondents. (World Bank Publications, 2006)

9. Mueller, V., Peterman, A., Billings, L. \& Wineman, A. Exploring Impacts of Community-Based Legal Aid on Intrahousehold Gender Relations in Tanzania. Fem. Econ. 25, 116-145 (2019)

10. Oktari, R. S., Kamaruzzaman, S., Fatimahsyam, F., Sofia, S. \& Sari, D. K. Gender mainstreaming in a Disaster-Resilient Village Programme in Aceh Province, Indonesia: Towards disaster preparedness enhancement via an equal opportunity policy. Int. J. Disaster Risk Reduct. 52, 101974 (2021)

11. Musawir, A. ul, Serra, C. E. M., Zwikael, O. \& Ali, I. Project Governance, Benefit Management, and Project Success: Towards a Framework for Supporting Organizational Strategy Implementation. Int. J. Proj. Manag. 35, 1658-1672 (2017)

12. Enriquez, D. \& Goldstein, A. COVID-19's Socioeconomic Impact on Low-Income Benefit Recipients: Early Evidence from Tracking Surveys. Socius 6, (2020)

13. Samudra, R. R. \& Setyonaluri, D. Inequitable Impact of COVID-19 in Indonesia: Evidence and Policy Response. Unesco 15 (2020)

14. Makridis, C. A. \& Wu, C. How Social Capital Helps Communities Weather The COVID-19 Pandemic. PLoS One 16, 1-18 (2021)

15. Siyam, N. \& Cahyati, W. H. Desa Siaga Demam Berdarah Dengue (DBD). J. Puruhita 1, 1-7 (2019)

16. Wilkinson, A. Local response in health emergencies: key considerations for addressing the COVID-19 pandemic in informal urban settlements. Environ. Urban. 32, 503-522 (2020)

17. Megahed, N. A. \& Ghoneim, E. M. Antivirus-built Environment: Lessons Learned from Covid-19 Pandemic. Sustain. Cities Soc. 61, 102350 (2020)

18. Ahsan, M. M. Strategic Decisions on Urban Built Environment to Pandemics in Turkey: Lessons from COVID-19. J. Urban Manag. 9, 281-285 (2020)

19. CNN Indonesia. Studi: Konsumsi Air Bersih Naik 3 Kali Lipat Saat Pandemi. CNN Indonesia (2021) 
20. Mursid, F. KLHK: Sampah Rumah Tangga Meningkat 36 Persen Saat Pandemi. (2021)

21. Jussim, L. Social perception and social reality: Why accuracy dominates bias and self-fulfilling prophecy. (OUP USA, 2012) 